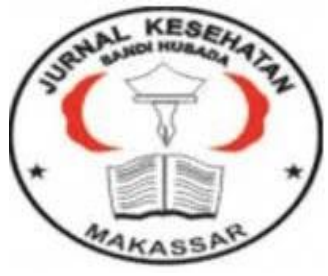

Jurnal Ilmiah Kesehatan Sandi Husada

hhttps://akper-sandikarsa.e-journal.id/JIKSH

Volume 9, Nomor 2, Desember 2020, pp 787-791

p-ISSN: 2354-6093 dan e-ISSN: 2654-4563

DOI: $10.35816 /$ jiskh.v10i2.405

\title{
Perilaku Swamedikasi
}

Self-Medicated Behavior

Laurensius Amedeo Sitindaon

Fakultas Kedokteran Universitas Lampung

Artikel info

Artikel history:

Received; Juli 2020

Revised: Agustus 2020

Accepted; Agustus 2020

\section{Abstrak}

Latar belakang: Swamedikasi merupakan perilaku mengkonsumsi obat sendiri berdasarkan diagnosis terhadap gejala sakit yang terjadi. Swamedikasi sendiri merupakan bagian dari "self care" yang merupakan usaha untuk mempertahankan kesehatan atau mencegah dan mengatasi penyakit. Perilaku swamedikasi pada masyarakat Indonesia tergolong tinggi. Tujuan: Mengetahui mengenai syarat, manfaat, resiko, dan penggunaan obat rasional pada perilaku swamedikasi. Metode: Metode yang digunakan merupakan metode studi literatur dari berbagai jurnal internasional dan website dengan jumlah literatur yang digunakan sebanyak 12 dan diambil dari rentang tahun 1998 hingga 2020. Hasil: Syarat perilaku swamedikasi, termasuk didalamnya membeli obat-obatan dengan menggunakan kembali atau mengirim kembali resep sebelumnya, mengambil obat-obatan atas saran keluarga atau orang lain, dan mengonsumsi obat-obatan sisa. Faktor utama yang mendasari perilaku swamedikasi adalah biaya pengobatan yang mahal, kurangnya pendidikan dan pengetahuan dalam bidang kesehatan. Swamedikasi memberikan solusi murah, cepat, dan nyaman dalam mengatasi penyakit ringan jika dilakuan berdasarkan penggunaan obatan rasional. Swamedikasi akan menghemat waktu dan biaya dalam mencari fasilitas kesehatan. Perilaku swamedikasi dapat menyebabkan berbagai masalah kesehatan jika dilakukan dengan tidak tepat. Kesimpulan: Swamedikasi memainkan peran yang penting sebenarnya dalam sistem pelayanan kesehatan. Perilaku swamedikasi yang tepat sesuai penggunaan obat rasional akan memberikan manfaat. Resiko perilaku swamedikasi akan muncul jika dilakukan dengan tidak tepat.

\section{Abstract}

Background: Self-medication is the behavior of taking one's own medication based on the diagnosis of the symptoms 
that occur. Self-medication itself is part of "self care" which is an effort to maintain health or prevent and overcome disease. Self-medicated behavior in Indonesian society is high. Objective: To find out about the terms, benefits, risks, and rational use of drugs in self-medicated behaviour. Method: The method used is a literature study method from various international journals and websites with 12 literatures used and taken from 1998 to 2020. Results: Selfmedication including buying drugs by reusing or sending back a previous prescription, taking medicines on the advice of family or other people, and consuming leftover medicines. The main factors underlying self-medicated behavior are high medical costs, lack of education and knowledge in the health sector. Self-medication provides a cheap, fast, and convenient solution to treating minor ailments if it is done based on rational drug use. Self-medication will save time and money in finding health facilities. Self-medicated behavior can lead to various health problems if done incorrectly. Conclusion: Self-medication plays an important role in the health care system. Self-medicated behavior appropriate to rational drug use will provide benefits. The risk of self-medicated behavior will arise if it is done inappropriately.

Keywords:

Behavior;

Self-medication;
Coresponden author:

Email: laurensiusasitindaon@gmail.com

artikel dengan akses terbuka dibawah lisensi CC BY 4.0

\section{Pendahuluan}

Pengobatan sendiri atau swamedikasi merupakan perilaku mengkonsumsi obat sendiri berdasarkan diagnosis terhadap gejala sakit yang dialami (Brata, Fisher, Marjadi, Schneider, \& Clifford, 2016). Swamedikasi sendiri merupakan bagian dari "self-care" yang merupakan usaha untuk mempertahankan kesehatan ataupun mencegah dan mengatasi penyakit (WHO, 2014). Swamedikasi sangat erat kaitannya dengan obat obatan "over the counter" (OTC) yang biasanya digunakan untuk mengobati penyakit ringan seperti sakit kepala, radang tenggorokan, flu dan demam, serta dismenore (Sawalha, 2007). Penggunaan obat obat herbal atau tradisional dan obat-obatan yang diperoleh dengan menggunakan kembali/mengirim kembali resep sebelumnya juga termasuk kedalam perilaku swamedikasi (Helal \& Abou-Elwafa, 2017).

Swamedikasi mempunyai beberapa keuntungan jika dilakukan dengan benar, diantaranya adalah menghemat waktu dan biaya dalam berobat pada fasilitas kesehatan (Lei, Jiang, Liu, Ferrier, \& Mugavin, 2018). Tidak dipungkiri swamedikasi juga memiliki beberapa resiko terutama di negara berkembang dengan populasi yang memiliki tingkat pengetahuan kesehatan yang rendah memperbesar resiko penggunaan obat yang tidak tepat (Ahmed, Sundby, Aragaw, \& Abebe, 2020). Perilaku swamedikasi pada masyarakat Indonesia tergolong tinggi. Pada tahun 2013, terdata sekitar $91 \%$ masyarakat Indonesia mempraktekkan swamedikasi (Ministry of Health Republic of Indonesia, 2016). Pola swamedikasi sendiri bervariasi di antara populasi berbeda dan dipengaruhi berbagai faktor seperti usia, jenis kelamin, pendapatan dan pengeluaran, orientasi perawatan diri, 
tingkat pendidikan, pengetahuan medis, kepuasan, dan keparahan penyakit (Helal \& AbouElwafa, 2017). Tingginya angka perilaku swamedikasi pada masyarakat Indonesia kemudian membentuk pertanyaan mengenai perilaku apa saja yang disebut swamedikasi, manfaat dan resiko perilaku swamedikasi, serta swamedikasi yang tepat.

\section{Metode}

Metode yang digunakan merupakan metode studi literatur dari berbagai jurnal internasional dan website . Studi literatur dilakuan menggunakan www.ncbi.nlm.nih.gov dan Google Schoolar sebagai sumber (digital library) dari pencarian literatur. Pencarian pada digital library menggunakan kata kunci Self Medication OR Self-medicated Behavior. Literatur yang digunakan berjumlah 12 dan diambil dari rentangtahun 1998 hingga 2020. Metode studi literatur mencari dan menggabungkan isi serta menganalisis fakta dari sumber ilmiah valid dan akurat. Studi literatur bertujuan untuk merangkum pemahaman terkini dari topik dengan cara meringkas topik pembahasan yang telah diterbitkan sebelumnya.

\section{Hasil Dan Pembahasan}

Beberapa perilaku yang dikategorikan sebagai swamedikasi adalah penggunaan obatobatan bebas (over the counter) terkadang termasuk juga obat-obatan yang diresepkan untuk mengobati gejala/penyakit berdasarkan diagnosis sendiri. Obat-obatan OTC ini biasanya tersedia di toko obat, toko retail, dan juga kios (Atmadani, Nkoka, Yunita, \& Chen, 2020). Swamedikasi, termasuk juga didalamnya membeli obat-obatan dengan menggunakan kembali atau mengirim kembali resep sebelumnya, mengambil obat-obatan atas saran keluarga atau orang lain, dan mengonsumsi obat-obatan sisa (Helal \& AbouElwafa, 2017). Obat obatan yang digunakan dalam swamedikasi selain obat OTC dan obat yang diresepkan, termasuk didalamnya adalah obat tradisional maupun obat herbal (Brata et al., 2016).

Faktor utama yang mendasari perilaku swamedikasi adalah obat-obatan dan biaya pengobatan yang mahal, kurangnya pendidikan dan pengetahuan dalam bidang kesehatan, obat-obatan yang tersedia secara bebas di toko-toko, menjual obat-obatan tanpa resep dokter dan kurangnya pengawasan ketat dari pemerintah terkait penyebaran obat, tidak tersedianya fasilitas medis, dan kemiskinan (Khan, 2018). Pengalaman sakit sebelumnya dan rekomendasi dari teman dan keluarga berdasarkan sakit yang pernah diderita juga menjadi faktor pendukung untuk melakukan swamedikasi (Ha, Nguyen, \& Nguyen, 2019). Pada penelitian yang dilakukan Helal dan Abou-Elwafa (2017), kalangan pelajar/mahasiswa menjadi salah satu pelaku swamedikasi tersering. Alasan utama yang mendukung swamedikasi dikalangan pelajar/mahasiswa adalah rekomendasi obat-obatan dari teman yang mayoritas merupakan pelajar/mahasiswa kesehatan dan tersedianya kotak obat pribadi (Helal \& Abou-Elwafa, 2017). Penelitian mengenai perilaku swamedikasi juga pernah dilakukan pada masyarakat Wuhan, China. Pada penelitan tersebut didapatkan bahwa mayoritas masyarakat melakukan swamedikasi dikarenakan penyakit yang diderita termasuk ringan dan tidak mempunyai waktu ke dokter (Lei et al., 2018).

Penelitian Swamedikasi di Indonesia telah beberapa kali dilakukan, diantaranya adalah perilaku swamedikasi pada wanita hamil. Selama kehamilan, obat OTC yang digunakan meliputi obat antiemetik (33\%), obat flu dan flu (29\%), obat anti demam (15\%), pereda nyeri (13\%), dan lain-lain (10\%). Perilaku swamedikasi tersebut didukung oleh tingkat pengetahuan yang baik mengenai penggunaan obat rasional dan bahaya terhadap wanita hamil (Atmadani et al., 2020). 
Swamedikasi memainkan peran yang penting sebenarnya dalam sistem pelayanan kesehatan (Lei et al., 2018). Bila dilakukan secara benar, swamedikasi seharusnya dapat membantu masyarakat dalam pengobatan sendiri secara aman dan efektif pada penyakitpenyakit ringan. Swamedikasi memberikan solusi yang murah, cepat, dan nyaman dalam mengatasi penyakit ringan. Swamedikasi menghemat lebih banyak waktu dan biaya dalam mencari fasilitas kesehatan (Helal \& Abou-Elwafa, 2017). Beberapa orang sering mendiagnosis masalah kesehatan mereka dengan membandingkan gejala dari penyakit diderita dengan orang lain yang didiagnosis dengan tanda dan gejala yang sama. Terkadang pengobatan yang disarankan sendiri dapat memberikan hasil yang positif (Khan, 2018).

Perilaku swamedikasi dapat menyebabkan berbagai masalah kesehatan jika dilakukan dengan tidak tepat. Potensi risiko yang terkait dengan swamedikasi adalah diagnosis penyakit yang salah, keterlambatan dalam mencari pengobatan yang diperlukan sehingga penyakit dapat menjadi lebih berat, cara pemberian yang salah, dan dosis yang salah (Ahmed et al., 2020). Swamedikasi yang tidak tepat juga dapat menyebabkan reaksi obat yang merugikan, overdosis, dan bahkan konsekuensi fatal. Saat ini, terdapat keprihatinan global tentang munculnya patogen yang resistan terhadap obat-obat terutama antibiotik, diperkirakan diperbesar dengan meningkatnya perilaku swamedikasi. Selain itu, pengobatan sendiri yang tidak tepat menyebabkan ketergantungan obat, pemborosan sumber daya, dan bahaya kesehatan yang serius (Amaha, etall, 2019). Swamedikasi memiliki resiko terhadap wanita hamil, terutama pada penggunaan obat-obat OTC. Penggunaan obat-obatan selama kehamilan merupakan dilema karena populasi yang rentan (yaitu, wanita hamil dan anak-anak) tidak dimasukkan dalam uji klinis obat. Oleh karena itu, tidak ada cukup data tentang efek obat tersebut pada kelompok rentan (Atmadani et al., 2020). Terlebih lagi, perilaku swamedikasi tidak sampai memperhitungkan keadaan yang berkaitan dengan interaksi antar obat, kehamilan, menyusui, penggunaan pada anak-anak dan orang tua, mengemudi, kondisi kerja, alkohol, atau makanan dibandingkan dengan obat yang diresep langsung oleh tenaga kesehatan yang berwenang (Amaha et al., 2019).

Penggunaan obat-obatan dalam swamedikasi yang sesuai dengan aturan dan kondisi penderita akan mendukung upaya penggunaan obat yang rasional. Kerasionalan penggunaan obat terdiri dari beberapa aspek, yaitu: ketepatan indikasi dalam mengkonsumsi obat, kesesuaian dosis penggunaan, ada tidaknya kontraindikasi, ada tidaknya efek samping dan interaksi dengan obat dan makanan, serta ada tidaknya penggunaan lebih dari dua obat untuk indikasi penyakit yang sama (Benítez, 1991). Pada obat-obat OTC atau yang akan digunakan dalam swamedikasi, perlu diperhatikan beberapa hal yang berkaitan dengan penggunaannya. Hal-hal tersebut berupa informasi yang menjelaskan cara penggunaan obat, kemungkinan efek samping obat, bagaimana efek obat harus dipantau, kemungkinan interaksi antat obat, tindakan pencegahan dan peringatan, durasi penggunaan, dan kapan harus melakukan pengobatan lanjutan. Biasanya informasi informasi tersebut tertera dalam kemasan obat (WHO, 2014).

\section{Simpulan Dan Saran}

Swamedikasi memainkan peran yang penting sebenarnya dalam sistem pelayanan kesehatan. Penggunaan obat-obatan dalam swamedikasi yang sesuai dengan aturan dan kondisi penderita akan mendukung upaya penggunaan obat yang rasional. Bila dilakukan secara benar, swamedikasi memberikan solusi yang murah, cepat, dan nyaman dalam mengatasi penyakit ringan. Potensi risiko yang terkait dengan swamedikasi yang tidak tepat adalah diagnosis penyakit yang salah, keterlambatan dalam mencari pengobatan 
yang diperlukan sehingga penyakit dapat menjadi lebih berat. Diharapkan artikel ini dapat menjadi dasar untuk penelitian lanjutan terutama pada kelompok rentan terhadap perilaku swamedikasi.

\section{Daftar Rujukan}

Ahmed, S. M., Sundby, J., Aragaw, Y. A., \& Abebe, F. (2020). Self-medication and safety profile of medicines used among pregnant women in a tertiary teaching hospital in jimma, ethiopia: A cross-sectional study. International Journal of Environmental Research and Public Health, 17(11).

Amaha, M. H., Alemu, B. M., \& Atomsa, G. E. (2019). Self-medication practice and associated factors among adult community members of Jigjiga town, Eastern Ethiopia. PLoS ONE, 14(6), 1-14.

Atmadani, R. N., Nkoka, O., Yunita, S. L., \& Chen, Y. H. (2020). Self-medication and knowledge among pregnant women attending primary healthcare services in Malang, Indonesia: A cross-sectional study. BMC Pregnancy and Childbirth, 20(1), 1-11. BMC Pregnancy and Childbirth.

Benítez, J. (1991). Preparing a personal formulary as part of a course in clinical pharmacology. Clinical Pharmacology and Therapeutics, 49(6), 606-608.

Brata, C., Fisher, C., Marjadi, B., Schneider, C. R., \& Clifford, R. M. (2016). Factors influencing the current practice of self-medication consultations in Eastern Indonesian community pharmacies: A qualitative study. BMC Health Services Research, 16(1), 1-10. BMC Health Services Research.

Retrieved from http://dx.doi.org/10.1186/s12913-016-1425-3

Ha, T. Van, Nguyen, A. M. T., \& Nguyen, H. S. T. (2019). Self-medication practices among Vietnamese residents in highland provinces. Journal of Multidisciplinary Healthcare, 12, 493-502.

Helal, R. M., \& Abou-Elwafa, H. S. (2017). Self-medication in university students from the city of mansoura, Egypt. Journal of Environmental and Public Health, 2017. Hindawi.

Khan, A. (2018). Health Complications Associated with Self-Medication. Journal of Physical Fitness, Medicine \& Treatment in Sports, 1(4), 2-5.

Lei, X., Jiang, H., Liu, C., Ferrier, A., \& Mugavin, J. (2018). Self-medication practice and associated factors among residents in Wuhan, China. International Journal of Environmental Research and Public Health, 15(1).

Ministry of Health Republic of Indonesia. (2016). 2015 Indonesia Health Profile. Retrieved from http://www.depkes.go.id/resources/download/pusdatin/profil-kesehatanindonesia/indonesian health profile 2015.pdf

Sawalha, A. F. (2007). Assessment of Self-Medication Practice among University Students in Palestine: Therapeutic and Toxicity Implications. The Islamic University Journal, 15(2), 67-82.

WHO. (2014). The Role of the Pharmacist in Self-Care and Self-Medication Contents. Who, $1-11$. 